\title{
Urethroplasty using a bovine pericardium graft: an experimental study using normal urethras from dogs
}

R.C. Lara ${ }^{1}$, A.M. Lucon ${ }^{2}$ and S. Arap ${ }^{2}$

\author{
${ }^{1}$ Departamento de Urologia, Faculdade de Medicina do Triângulo Mineiro, \\ Uberaba, MG, Brasil \\ ${ }^{2}$ Divisão de Urologia, Faculdade de Medicina, Universidade de São Paulo, \\ São Paulo, SP, Brasil
}

\section{Correspondence \\ R.C. Lara \\ Rua Constituição, 788, Sala 203 \\ 38026-280 Uberaba, MG \\ Brasil \\ Fax: +55-34-3312-8181 \\ E-mail: rolflara@mednet.com.br}

Publication supported by FAPESP.

$\ldots \ldots \ldots \ldots \ldots \ldots \ldots$

Received October 15, 2002

Accepted November 6, 2003

\begin{abstract}
The use of bovine pericardium as a urethral patch to substitute a ventral segment of canine urethras was studied. Healing, epithelial growth, urethral permeability, fistulas, and calcification were analyzed. Thirty male mongrel dogs of medium and large size underwent resection of a ventral segment of the medial urethra measuring $2.0 \mathrm{x}$ $0.5 \mathrm{~cm}$, which was replaced with a bovine pericardium graft, treated with buffered glutaraldehyde and preserved in formaldehyde. Two running sutures of polygalactin 5-0 were applied, one on each side of the patch. The corpus spongiosum was closed with uninterrupted suture and the skin with interrupted suture of polygalactin 5-0. Six months later, the animals were examined and sacrificed under anesthesia. Retrograde urethrograms showed that the urethral healing was complete in six of the 30 animals, without stenosis, fistulas or dilations. Microscopic examination showed complete epithelization of these six urethras. The remaining 24 animals presented urethrocutaneous fistulas without stenosis, demonstrated by urethral catheterism using a 10-Fr plastic catheter. These data show that a successful urethral reconstruction of the penile urethra was possible in only $20 \%$ of the operated animals. Infection and leakage may be the cause of the urethrocutaneous fistulas present in $80 \%$ of cases. Further studies are necessary to determine whether such fistulas are avoidable. If they are, the bovine pericardium may well be an option in the treatment of urethral lesions in dogs.
\end{abstract}

\section{Introduction}

Several kinds of tissue have been used to correct complex urethral lesions: vein (1), vermiform appendix (2), uterine tube (3), ureter (4), skin (5), bladder mucosa (6), buccal mucosa (7), dura mater (8), peritoneum (9), tunica vaginalis (10), and preputial island flap (11). The best results have been
Key words

- Urethra

- Urethral stricture

- Bovine pericardium 
results and without immunological rejection or infection. Bovine pericardium may also be a good option for urinary tract reconstruction because of its availability and low cost. In the present investigation we studied its use in reconstructions of urethral defects experimentally induced in dogs.

\section{Material and Methods}

The study was approved by the Ethics Committee of the University of São Paulo School of Medicine. Thirty male mongrel dogs of medium and large size were operated upon.

The animals were anesthetized with 3\% sodium pentobarbital administered in fractionated doses as needed through a cannulated vein of the dog. Each animal received 400,000 IU procaine penicillin, 600,000 IU benzathine penicillin G, plus $40 \mathrm{mg}$ of gentamicin. A 10-Fr plastic catheter was introduced into the bladder through the urethra. An incision was made in the ventral surface of the penis, the medial urethra was exposed and a segment of $2.0 \times 0.5 \mathrm{~cm}$ was resected. A patch of Fisics/INCOR ${ }^{\circledR}$ (Fisics Biofísica Aplicada, S/A, Água Branca, SP, Brazil) bovine pericardium was washed in $0.9 \%$ saline and used to correct the defect. Two running sutures of polygalactin 5-0 were applied, one on each side of the patch (Figure 1). The corpus spongiosum was closed with uninterrupted suture and the skin with interrupted suture of polygalactin 5-0.

The urethral catheter was cut at the end of the penis, fixed with two propylene 3-0 stitches, and removed 10 days later. During this period the animals received $40 \mathrm{mg}$ gentamicin a day. They were divided into groups of 5 animals per cage in the animal facility and fed once a day.

After six months, 29 animals were examined under anesthesia and retrograde urethrograms were performed on the dogs with no macroscopic urethral defects. Next, the animals were killed and the penis was resected for examination. The dogs with urethral defects and urine leakage had their urethras gently catheterized with 10-Fr catheters to determine urethral permeability. They were killed and had their penis resected for examination. The specimens were stained with hematoxylin and eosin for microscopic study. One of the animals died of a respiratory infection four months after the surgery, when a retrograde urethrogram was performed followed by penis study.

\section{Results}

Retrograde urethrograms showed normal

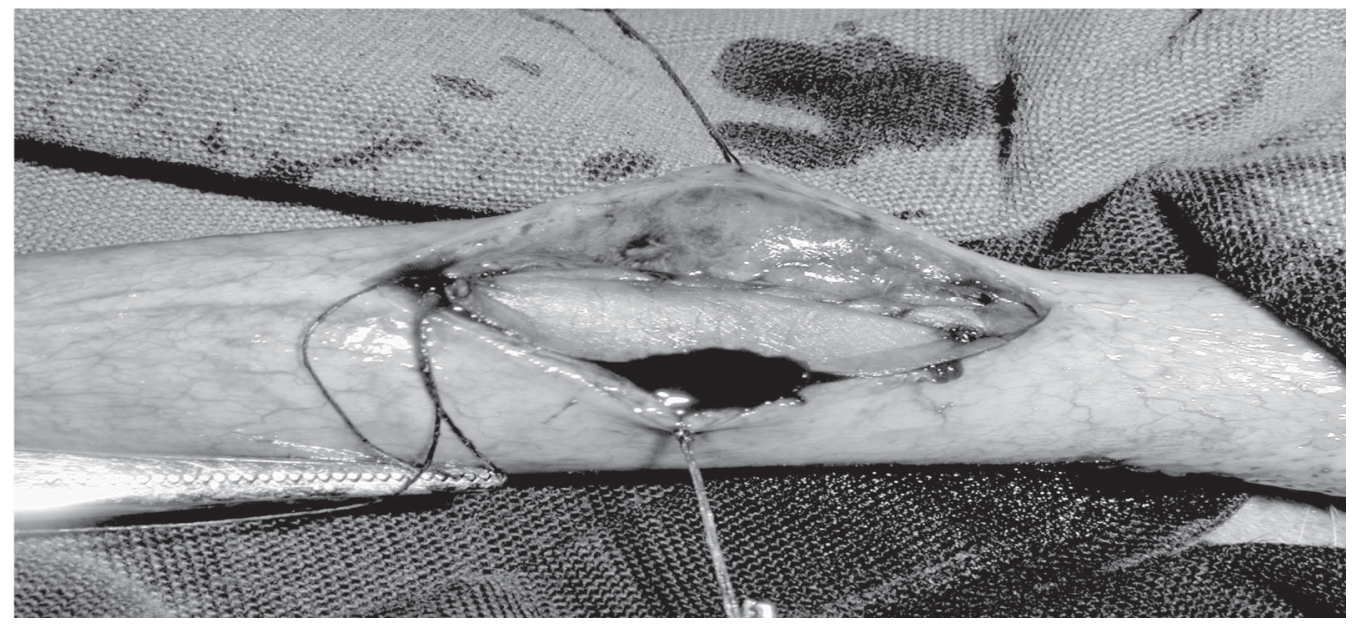

Figure 1. Bovine pericardium patch sutured to correct the urethral defect induced in a dog. 
urethras without stenosis, leakage, or dilations in six animals. The dog that died four months after surgery was included in this group. A small amount of the iodine contrast injected into the urethras was observed in the corpus spongiosum of all these six dogs. The microscopic study of these urethras showed complete epithelial growth over the graft site with infiltration of mononuclear inflammatory cells in the mucosa. No granulomas or calcification were observed (Figure 2). It was only possible to identify the graft in one of these six animals.

Twenty-four dogs had urethral fistulas. The urethral catheterization of these animals was performed easily using 10-Fr catheters. The penises showed fistulas connecting the urethras to the skin of the patch graft. Histology revealed a normal epithelium with migration of inflammatory cells. There was no evidence of a residual pericardial graft, active granulation, or calcification in any of the six animals studied.

\section{Discussion}

The search for an ideal urethral substitute is a challenge. Several attempts have been made to correct urinary tract system defects using various materials. Memmelaar (19) was the first to describe the use of bladder mucosa to create a neourethra in 1947 , and many studies using bladder mucosa were published since then with varying sucess rates. Complications occur in 12 to $76 \%$ of cases. The major ones are meatal and anastomotic stenosis and urethral fistulas $(6,20-$ 22).

Buccal mucosa has also been used for urethral reconstruction. Humby (23) was the first to use buccal mucosal grafts for urethroplasty in 1941. Buccal mucosa may be used as a patch graft with good results in 89 to $100 \%$ of cases, with urethral strictures occurring in $11 \%$ and fistulas in $6 \%$ of the patients. Tubularized buccal mucosal grafts produce successful results in 55 to $60 \%$ of the reconstructions, urethral strictures in 40 to $45 \%$, and fistulas in 6 to $45 \%(7,24-26)$.

Tunica vaginalis has been used for urethral reconstructions in humans, with disappointing results. Urethral stricture is present in $60 \%$ of the patch grafts and in all tubularized cases (27).

Dura mater has been used for urethral reconstructions and the results vary among series $(8,28)$. Villavicencio et al. (8) reported treatment of 131 patients using dura mater. A patch graft was used in 124 cases and a tubular graft in seven. Average follow-up was 56.6 months and success was obtained in $41 \%$ of cases. In the seven patients in which a tubular graft was performed there was a recurrence of the stricture.

The bovine pericardium used for bladder substitution is biodegradable and allows com-

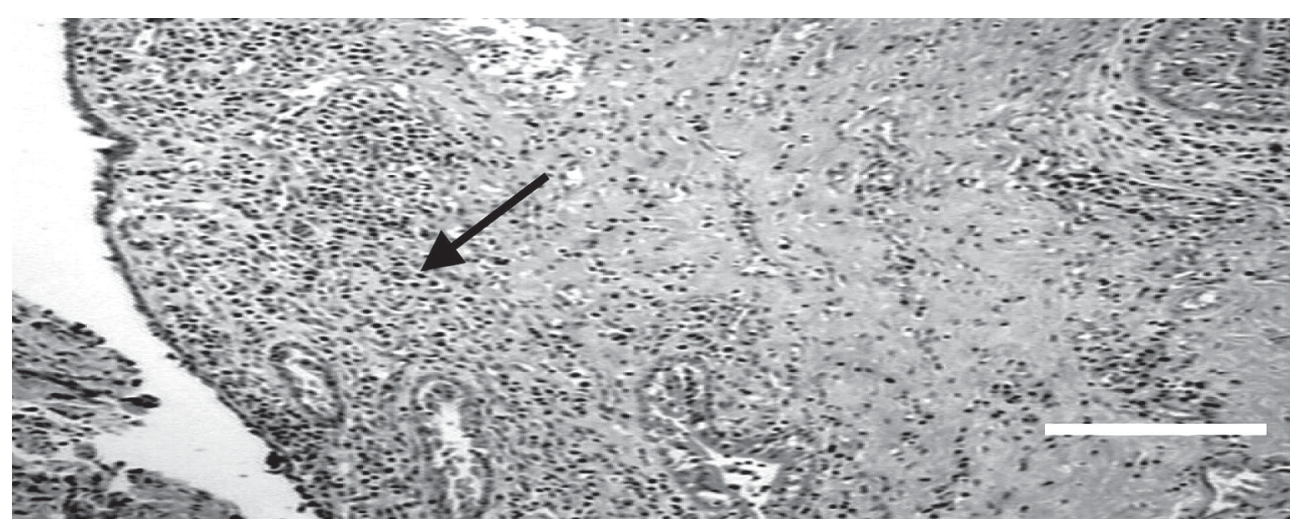

Figure 2. Transverse microscopic section through the urethra repaired with a bovine pericardium graft, showing inflammatory cells (arrow) in the mucosa and epithelial growth (HE, Bar $=100 \mu \mathrm{m})$. 
plete epithelization within 4 to 8 weeks (2932). The question of bladder muscle regeneration is controversial. Several reports have shown incomplete muscle regeneration $(30,32,33)$, while others have found no regeneration $(29,31)$.

In the present study the bovine pericardium worked as a matrix for normal epithelial growth in the urethra of 6/30 dogs. In five of these cases it was found that the urethras were normal. It was only possible to identify the graft in one of these animals. Eighty percent of the cases 24/30 had urethrocutaneous fistulas. The method used in the present study permitted no conclusion as to the reason for this occurrence. The use of bovine pericardium in bladder substitution does not result in such a high incidence of complications (29,33-36). Local infection of the urethras may be the cause of the fistulas. Another possibility is that a vesicostomy may be a better technique for urinary diversion than a urethral catheter because it prevents urinary infiltration through the suture lines.

In 5 of the 6 successful cases with no fistula there was no residual pericardial graft, which confirms the absorption of the bovine pericardium (29,33-36). Emphasis should be placed on the fact that the grafts were used to correct urethral defects in normal urethras with good surrounding tissue, which is not the case in urethral strictures.

Urethral reconstruction represents an area of clinical urologic surgery in which the search for an ideal tissue continues. Atala (37) has been carrying out tissue engineering studies. A biopsy of tissue is obtained from the host, and the cells are dissociated and expanded in vitro, attached to a matrix, and reimplanted in the same host. Studies are being conducted on animals using these techniques for the substitution of urethras, bladders and ureters (37). Our result of $20 \%$ success employing biodegradable materials suggests that this approach is viable but more studies are required.

\section{Acknowledgments}

I would like to thank Prof. Dr. Vicente de Paula Antunes Teixeira for contributing to the pathology studies and Luiz Gonzaga Silveira Filho for performing the urethrograms, both from Faculdade de Medicina do Triângulo Mineiro, Uberaba, MG, Brazil.

\section{References}

1. Kahveci R, Kahveci Z, Sirmali S \& Özcan M (1995). Urethral reconstruction with autologous vein graft: an experimental study. British Journal of Plastic Surgery, 48: 500-503.

2. Sheldon CA \& Gilbert A (1992). Use of the appendix for urethral reconstruction in children with congenital anomalies of the bladder. Surgery, 112: 805-811.

3. Barroso UJ, Duel B, Barthold JS \& González R (1999). Orthotopic urethral substitution in female patients using the Mitrofanoff principle. Journal of Urology, 161: 251-253.

4. Mitchell ME, Adams MC \& Rink RC (1988). Urethral replacement with ureter. Journal of Urology, 139: 1282-1285.

5. Valla JS, Takvorian P, Galifer RB, Chavrier Y, Aubert D, MorrissonLacombe G, Montupet P, Reinberg O \& Dyon JF (1991). Singlestage correction of posterior hypospadia (178 cases). Comparison of three techniques: free skin graft, free bladder mucosal graft, transverse pedicle preputial graft. European Journal of Pediatric Surgery, 1: 287-290.

6. Kinkead TM, Borzi PA, Duffy PG \& Ransley PG (1994). Long-term follow-up of bladder mucosa graft for male urethral reconstruction. Journal of Urology, 151: 1056-1058.
7. Andrich DE \& Mundy AR (2001). Substitution urethroplasty with buccal mucosal-free grafts. Journal of Urology, 165: 1131-1133.

8. Villavicencio $H$, Moreno RP, Sariol JC, Briones JR, Bordes AR \& Rodríguez JV (1998). Experience with lyophilized human dura mater for urethral strictures. Journal of Urology, 160: 1310-1311.

9. Shaul DB, Xie HW, Diaz JF, Mahnoviski V \& Hardy BE (1996). Use of tubularized peritoneal free grafts as urethral substitutes in the rabbit. Journal of Pediatric Surgery, 31: 225-228.

10. Theodorescu D, Balcom A, Smith CR, Mclorie GA, Churchill BM \& Khoury AE (1998). Urethral replacement with vascularized tunica vaginalis: defining the optimal form of use. Journal of Urology, 159: 1708-1711.

11. Wiener JS, Sutherland RW, Roth DR \& Gonzales Jr ET (1997) Comparison of onlay and tubularized island flaps of inner preputial skin for the repair of proximal hypospadias. Journal of Urology, 158: 1172-1174

12. Borer JG \& Retik AB (1999). Current trends in hypospadias repair. Urologic Clinics of North America, 26: 15-37.

13. Duckett JW (1998). Hypospadias. In: Walsh PC, Retik AB \& Vaughan Wein AJ (Editors), Campbell's Urology. Vol. 2. Saunders, Philadel- 
phia, PA, USA, 2093-2119.

14. Pomerantzeff PMA, Brandão CMA, Cauduro $P$ et al. (1997). Biopróteses de pericárdio bovino Fisics-Incor: 15 anos. Revista Brasileira de Cirurgia Cardiovascular, 12: 359-366.

15. Grimsley BR, Wells JK, Pearl GJ, Garrett WV, Shutze WP, Talkington CM, Gable DR, Smith BL \& Thompson JE (2001). Bovine pericardial patch angioplasty in carotid endarterectomy. American Surgeon, 67: 890-895.

16. Del Campo C \& Fonseca A (2001). Replacement of the left common iliac vein with a custom-made bovine pericardium tubular graft. Texas Heart Institute Journal, 28: 39-41.

17. Filippi R, Schwarz M, Voth D, Reisch R, Grunert P \& Perneczky A (2001). Bovine pericardium for duraplasty: clinical results in 32 patients. Neurosurgical Review, 24: 103-107.

18. Egydio PH (2000). Correção da deformidade na doença de Peyronie com incisão circunferencial incompleta em duplo y na placa não tubularizada e enxerto de pericárdio bovino. Doctoral thesis, Faculdade de Medicina, Universidade de São Paulo, São Paulo, SP, Brazil.

19. Memmelaar J (1947). Use of bladder mucosa in one-stage repair of hypospadias. Journal of Urology, 58: 68-73.

20. Coleman JW, Mcgovern JH \& Marshall VF (1981). The bladder mucosal graft technique for hypospadias repair. Urologic Clinics of North America, 8: 457-462.

21. Koyle MA \& Ehrlich RM (1987). The bladder mucosal graft for urethral reconstruction. Journal of Urology, 138: 1093-1095.

22. Mollard P, Mouriquand $P$, Bringeon G \& Bugmann P (1989). Repair of hypospadias using bladder mucosal graft in 76 cases. Journal of Urology, 142: 1548-1550.

23. Humby GA (1941). A one-stage operation for hypospadias. British Journal of Urology, 24: 84-92.

24. Morey AF \& McAninch JW (1996). When and how to use the buccal mucosal grafts in adult bulbar urethroplasty. Urology, 48: 194-198.

25. Fichtner J, Fisch M, Filipas D, Thuroff JW \& Hohenfellner R (1998). Refinements in buccal mucosal grafts urethroplasty for hypospadias repair. World Journal of Urology, 16: 192-194.
26. Pansadoro V, Emiliozzi P, Gaffi M \& Scarpone P (1999). Buccal mucosa urethroplasty for the treatment of bulbar urethral strictures. Journal of Urology, 161: 1501-1503.

27. Joseph DB \& Perez LM (1999). Tunica vaginalis onlay urethroplasty as a salvage repair. Journal of Urology, 162: 1146-1147.

28. Valor PC, Garcia-Matres MJ, Alonso-Dorrego JM, Cardoso JVG \& Martinez-Piñeiro JA (1995). Uretroplastia con duramadre humana liofilizada. Archivos Españoles de Urología, 48: 681-683.

29. Agishi T, Nakazono M, Kiraly RJ, Picha G \& Nosé Y (1975). Biodegradable material for bladder reconstruction. Journal of Biomedical Materials Research Symposium, 6: 119-131.

30. Novick AC, Straffon RA, Banowsky LH, Nose Y, Levin H \& Stewart $\mathrm{BH}$ (1977). Experimental bladder substitution using biodegradable graft of natural tissue. Urology, 10: 118-127.

31. Kambic H, Kay R, Chen JF, Matsushita M, Harasaki H \& Zilber S (1992). Biodegradable pericardial implants for bladder augmentation: a 2.5 year study in dogs. Journal of Urology, 148: 539-543.

32. Amaro JL, Fabri V, Curi PR \& Trindade JCS (2000). Alterações histológicas na ampliação vesical com dura-máter e pericárdio bovino: estudo comparativo em coelhos. Jornal Brasileiro de Patologia, 36: 178-184.

33. Goldstein MB, Gualtiere V \& Getzoff PL (1970). Expansion mechanisms of the partially cystectomized bladder: an experimental study in rabbits. Journal of Urology, 164: 413-417.

34. Anwar H, Dave B \& Seebode JJ (1984). Replacement of partially resected canine urethra by polytetrafluoroethylene. Urology, 24: 583-586.

35. Olsen L, Bowald S, Busch C, Carlsten J \& Eriksson I (1992). Urethral reconstruction with a new synthetic absorbable device. Scandinavian Journal of Nephrology, 26: 323-326.

36. Da Silva EA \& Zungri Telo E (2000). Urethral substitution with synthetic material. Actas Urológicas Españolas, 24: 235-242.

37. Atala A (2000). Tissue engineering of artificial organs. Journal of Endourology, 14: 49-57. 